\title{
Comparative Studies of Lead and Heavy Metals Concentrations in Pakistan Soil and Its Toxic Effects
}

\author{
Asrar Ahmad", Shabbir Hussain', Sajid Mahmood Rao", Amina Asghar ${ }^{1}$, \\ Misbah Irshad', Muhammad Aslam¹, Syed Salman Shafqat', Mohsin Javed ${ }^{3}$, \\ Muhammad Shahzad Bashir ${ }^{4}$, Hafiza Samreen Kausar ${ }^{2}$ \\ ${ }^{1}$ Department of Chemistry, University of Education Township, Lahore. \\ ${ }^{2}$ Department of Chemistry, Lahore Garrison University, DHA Lahore, Pakistan. \\ ${ }^{3}$ Department of Chemistry, University of Management and Technology, Lahore, Pakistan \\ ${ }^{4}$ Department of Chemistry, GC University Faisalabad, Faisalabad, Pakistan
}

Received: 4 November 2018

Accepted: 28 March 2019

\begin{abstract}
A study was conducted to determine qualitative and quantitative lead contamination in soil along two major roadsides (Motorway M-2 and National Highway N-5) of Thokar Niaz Baaig (TNB) in Lahore, and adjoining areas of the Hudiara drain in Pakistan by employing the digestion method using $\mathrm{HCl} / \mathrm{HNO}_{3}$ at 1:4. The characterization of lead $(\mathrm{Pb})$ was performed by atomic absorption spectroscopy. High deposition of lead was observed along the soil of linking roads of rather populated towns of Lahore, Pakistan, and the soil irrigated by the wastewater of Hudiara drain. The lead contents originated mainly from vehicular emissions, urban pollution and industrial effluents, and may lead to a rise of lead levels in the vegetation of associated areas. The present study also explores a comparison of heavy metal $(\mathrm{Pb}, \mathrm{Cu}, \mathrm{Cd}, \mathrm{Zn}, \mathrm{Ni}, \mathrm{Fe}, \mathrm{Mn}, \mathrm{Cr}, \mathrm{Ti})$ concentrations in different areas of Pakistan and its adverse effects on plant growth. There is a need to strictly monitor the water quality in the Hudiara drain; its wastewater should be avoided for irrigation purposes. Some fungal strains can also be used to control the heavy metal concentration in such polluted water. However, some beneficial effects of Hudiara drain wastewater as a nutritional source for plants have also been suggested. It is important to establish the proper nutrition conditions in areas of contaminated soil.
\end{abstract}

Keywords: lead, heavy metals, soil, Pakistan, toxic

*e-mail: dr.shabbirhussain@lgu.edu.pk 


\section{Introduction}

Heavy metals such as lead, mercury, nickel, chromium, cadmium and arsenic are potentially toxic to humans, animals and crops. They are important environmental pollutants, especially in areas with high anthropogenic pressure [1]. In such areas the disposal of industrial wastes and sewage water causes a great problem for agricultural lands [2,3]. Since the soil has the ability to bind a variety of chemicals, it acts as a major reservoir for contaminants [4]. When the soil becomes contaminated, metals are dissolved in solution, undergo absorption by inorganic and organic soil particles, and form a complex with the soil water [5].

Lead is widely utilized for the manufacture of storage batteries, alloy formation and casting, etc. Soil is contaminated by the exposure of lead through direct intake from infected dust or air. Generally garden soil is thought to be safe when lead amounts to less than $300 \mathrm{ppm}$. When the concentration of a heavy metal is higher than the allowable range, it causes damage to the biological life and also affects enzyme activities and microbial action [6]. Lead in its ionic form is absorbed by plants from the soil and is accumulated majorly in plant roots [7]. The selection of proper fertilizers and the time of cultivation greatly affect lead uptake by plants from the soil [8]. Due to the use of tetraethyl lead in petrol, the atmospheric emissions have always been found to contain lead [9], which is highly toxic to human beings since it causes the replacement of calcium and is itself accumulated in the skeletal system [10]. Due to extensive utilization of lead in the fuel and paint industries, soil in industrial cities is contaminated. Lead is not degraded by living organisms, so a heavy amount may cause severe health issues. Exposure to lead in early and mature life has a strong impact on mothers and their babies [11]. Exposed children may have behavioral problems, disabilities, delayed learning, etc. Contamination in homes is due to clothes, shoes and other routine articles [12].

Higher concentrations of heavy metals in water, soil and atmosphere cause serious problems to all organisms, and can result in bioaccumulation, which may be highly dangerous for human health. Various studies have been performed in Pakistan over the past few years to assess the heavy metal contamination in soil, water, vegetables, particulate matter and sediments [13].

In the current studies, efforts have been made to find the amount of $\mathrm{Pb}$ in soil samples collected from the close proximity of Hudiara drainage and two major roadsides (a motorway and national highway) of Lahore. Hudiara drain originates from Gurdaspur District, India, and enters Pakistan near Laloo village. It takes wastewater and sewage from various industries and residential areas and disposes of it in the Ravi River. Since most of the farmers have no idea about the detrimental effects of industrial effluents and sewage water, they irrigate their crops after every 5 or 6 days with the wastewater of Hudiara Drain in the adjoining areas, which causes severe problems.

\section{Materials and Methods}

Soil samples were collected from close proximity of Hudiara drainage and two major roadsides: Motorway (M-2) and National Highway (N-5) of Thokar Niaz Baaig (TNB), Lahore, Pakistan (Fig. 1).

Soil samples were taken in triplicate at distances of $25 \mathrm{~m}, 50 \mathrm{~m}, 75 \mathrm{~m}$ and $100 \mathrm{~m}$ from roadsides in November. The samples were collected up to a depth of $16 \mathrm{~cm}$ in soil with a core extractor of $2.6 \mathrm{~cm}$ width. $1.5 \mathrm{~kg}$ soil from every site was taken in polyethylene bags for specific evaluation. Soil was air-dried at $25^{\circ} \mathrm{C}$ (room temperature) and then crushed into very fine

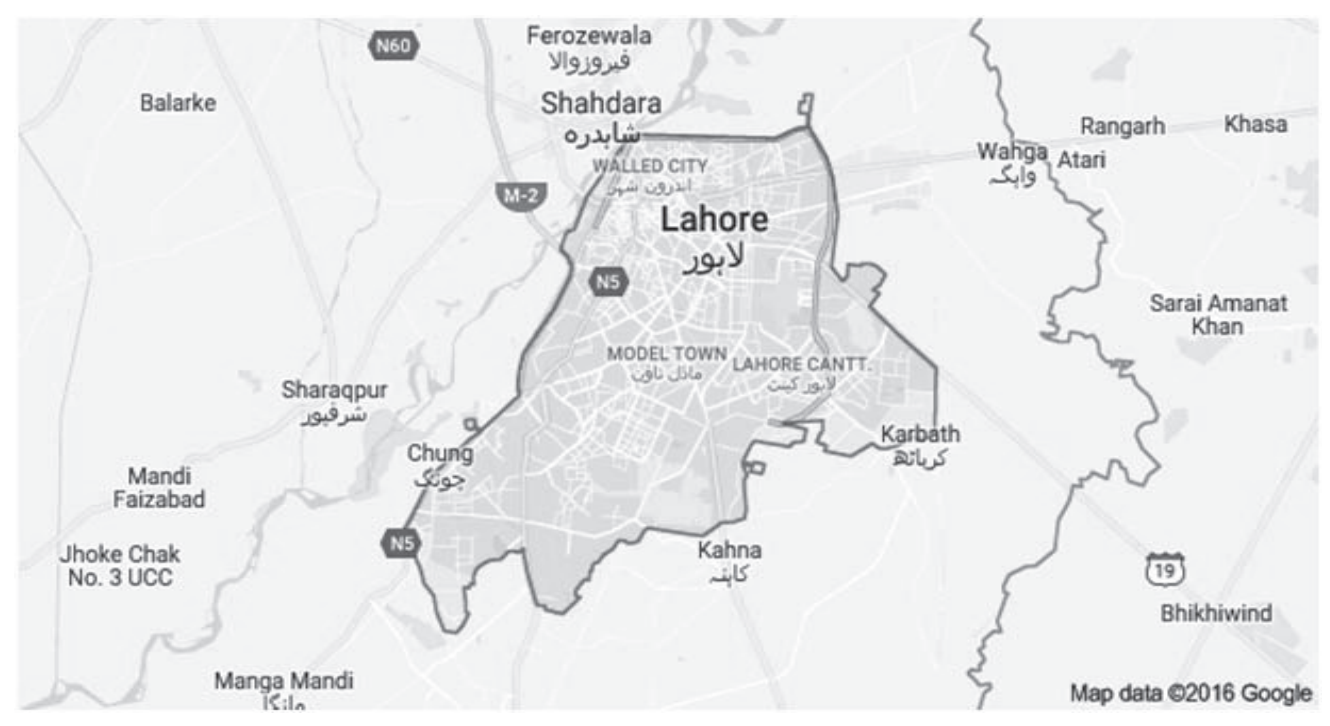

Fig. 1. Map showing locations of motorway (M-2) and national highway (N-5) in Lahore. 



Fig. 2. Lead levels in roadside soil samples from TNB to MW a) at location 1, b) at location 2, and c) at location 3; the $x$-axis indicates distance in meters from the edge of the road while the y-axis indicates concentration of lead in ppm.

powder in a ceramic mill. Soil samples were kept in an aluminum digestion block and heated for complete digestion to calculate the lead concentration by nicely calibrated atomic absorption spectrometer. Three readings were taken and then their mean was calculated [14].

At every sampling place, about $0.5 \mathrm{~kg}$ of soil was collected $0-15 \mathrm{~cm}$ deep by using a sampler composed of steel. Twenty samples were taken from different points, carefully homogenized in a sanitary plastic pot, dried, ground and then filtered with $2.5 \mathrm{~mm}$ pores before being kept in labeled plastic bags prior to analysis. Samples of air-dried soil were marked according to the regions from which they were obtained. $2 \mathrm{~g}$ of all soil samples were bench-dried for 5 days in the lab and then crushed to very fine particles in a mortar with pestle. Sample solutions in water were shaken for 3 minutes, filtered and heat-dried in an oven for 24 hours.

\section{Results and Discussion}

Lead Concentration Along the Sides of the Motorway and National Highway in Thokar Niaz Baaig (TNB), Lahore, Pakistan

Fig. 2 shows lead levels in roadside soil samples from TNB to M-2 at locations 1-3. The graphs (a-c) in Fig. 2 show that there is a decrease in the lead concentration in the test soil as the distance of the sampling site from the road edges is increased.

All the graphs in Fig. 2 clearly depict that the concentration of lead is higher near the edges of the road and the $\mathrm{Pb}$ concentration is lower in the soil that is away from the road edges. This is due to increased pollution load near the roadside areas. Lead concentration is decreased by increasing distance from the source of pollutants [15]. These observations are further augmented from the similar results when the Warmia and Masuria region of Poland was studied for soil contamination by lead, which was found in the highest concentration near the starting point $(10 \mathrm{~m}$ from the road edge) [16]. These results are further verified from the studies carried out on soil samples collected from upper horizons of black earth and grey-brown podsolic soils in the neighborhood of Legnica Copper Works. The amount of lead was decreased by increasing the distance from the emission source [17], which reflected a decrease in the rate of aerial deposition [18]. Actually, when we move away from roads, air pollution is decreased; the road edges have more smoke and pollution load. Heavy traffic causes a high discharge of lead content in the air, which shows more pronounced effects in nearby locations of roadsides as compared to the distant sites. At a distance of $25 \mathrm{~m}$ (Location 1, Fig. 2a) from the roadside, the concentration of lead is $25 \mathrm{mg} / \mathrm{kg}$, but moving up to a distance of $100 \mathrm{~m}$ from the road edge, the lead concentration was decreased to $14 \mathrm{mg} / \mathrm{kg}$. At location 2 (Fig. 2b), the lead concentration was found to be $32 \mathrm{mg} / \mathrm{kg}, 25 \mathrm{mg} / \mathrm{kg}, 23 \mathrm{mg} / \mathrm{kg}$ and $09 \mathrm{mg} / \mathrm{kg}$ at distances of $25 \mathrm{~m}, 50 \mathrm{~m}, 75 \mathrm{~m}$ and $100 \mathrm{~m}$, respectively. At location 3 (Fig. 2c), the lead concentration was $30 \mathrm{mg} / \mathrm{kg}, 27 \mathrm{mg} / \mathrm{kg}, 26 \mathrm{mg} / \mathrm{kg}$ and $08 \mathrm{mg} / \mathrm{kg}$ at distances of $25 \mathrm{~m}, 50 \mathrm{~m}, 75 \mathrm{~m}$ and $100 \mathrm{~m}$, respectively.

Graphs (a-c) in Fig. 3 demonstrate the lead levels in roadside soil samples from TNB to Saman Abad in locations 1-3. In location 1 (Fig. 3a), the lead concentration is $125 \mathrm{mg} / \mathrm{kg}$ at a distance of $25 \mathrm{~m}$ from the road edge, but moving up to a distance of $100 \mathrm{~m}$, lead concentration decreases significantly to $05 \mathrm{mg} / \mathrm{kg}$. In location 2 (Fig. 3b), the lead concentration is $99 \mathrm{mg} / \mathrm{kg}, 93 \mathrm{mg} / \mathrm{kg}, 60 \mathrm{mg} / \mathrm{kg}$ and $20 \mathrm{mg} / \mathrm{kg}$ at distances of $25 \mathrm{~m}, 50 \mathrm{~m}, 75 \mathrm{~m}$ and $100 \mathrm{~m}$, respectively. In location 3 (Fig. 3c), the lead concentration is $86 \mathrm{mg} / \mathrm{kg}, 80 \mathrm{mg} / \mathrm{kg}, 55 \mathrm{mg} / \mathrm{kg}$ and $10 \mathrm{mg} / \mathrm{kg}$ at distances of $25 \mathrm{~m}, 50 \mathrm{~m}, 75 \mathrm{~m}$ and $100 \mathrm{~m}$, respectively.

Graphs (a-c) in Fig. 4 show the comparison of lead in soil samples along roadsides of the national highway and motorway at locations 1-3. It is obvious from 

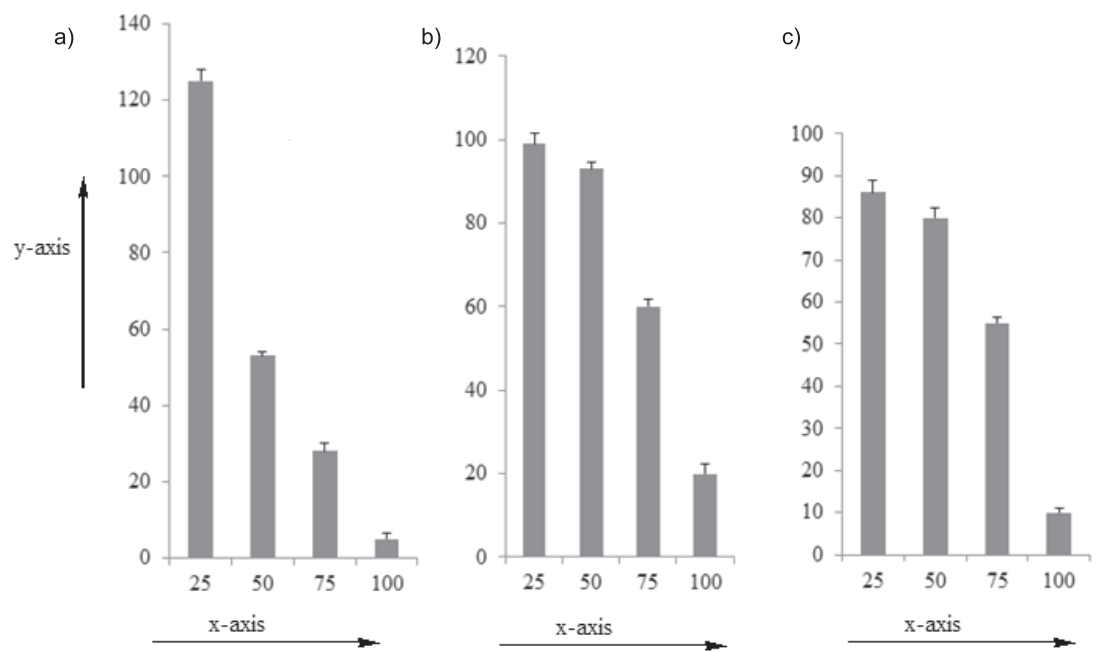

Fig. 3. Lead levels in roadside soil samples of National Highway N-5 from TNB to Samanabad: a) at location 1, b) at location 2, and c) at location 3; the $\mathrm{x}$-axis indicates distance in meters from the edge of the road while the y-axis indicates the concentration of lead in ppm.

Fig. 3 that lead concentrations at all the tested locations 1-3 (Fig. 4a-c) are higher at the national highway as compared to the motorway. The reason is that on the motorway traffic density is comparatively low and there is more plantation and open environment so that air pollution is less, but on national highway N-5 from TNB to Saman Abad the heavy traffic discharges cause an increase of lead concentration. This heavy traffic uses diesel (instead of petrol), which contains tetra ethyl lead, thus discharging more lead. Similar studies [19] on the soil samples of Lodz, Poland, demonstrate that the main sources of lead contamination are heavy motor traffic and large industrial plants. Powerplant dust has no role in this regard [19]. Soil is usually tested with respect to $\mathrm{Hg}, \mathrm{Cu}, \mathrm{Zn}, \mathrm{Cd}$ or $\mathrm{Pd}$ content, since these metals especially disturb the chemical equilibrium in an ecosystem [20].

Similar studies were conducted to determine lead contamination in soil and vegetation along two major roadsides (national highway and motorway) between Lahore and Faisalabad, Pakistan, using laser-induced breakdown spectroscopy and atomic absorption
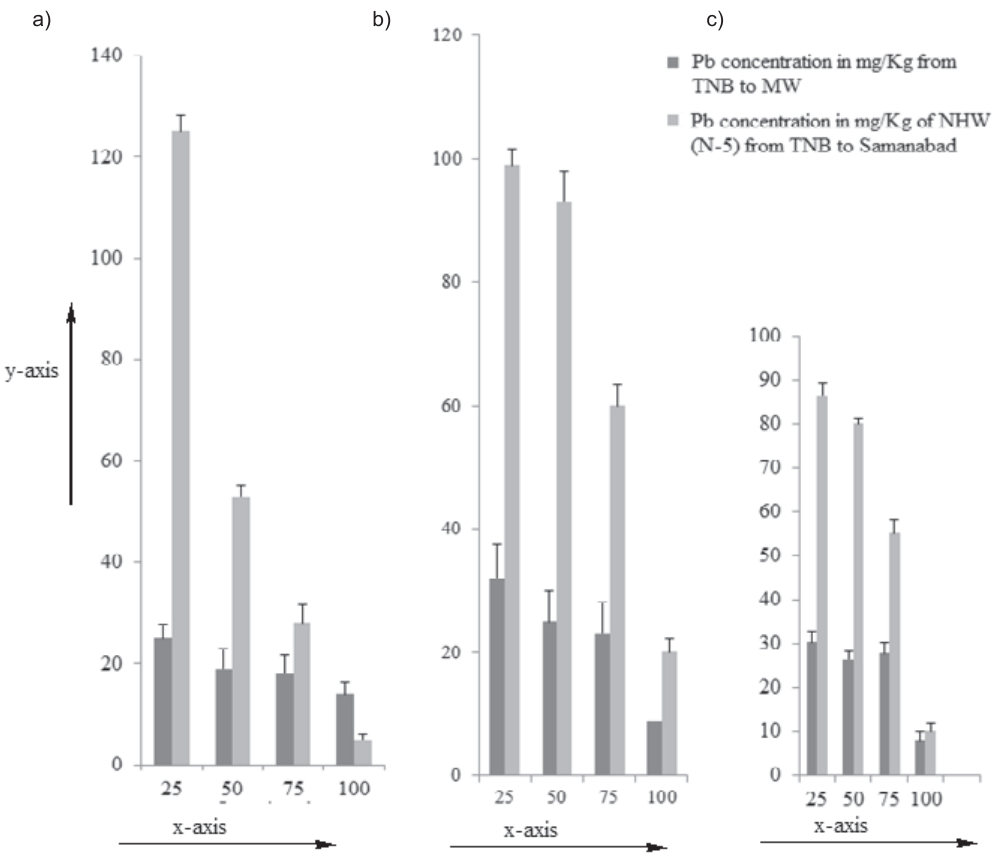

c)

$\mathrm{Pb}$ concentration in $\mathrm{mg} / \mathrm{Kg}$ from TNB to MW

Pb concentration in $\mathrm{mg} / \mathrm{Kg}$ of $\mathrm{NHW}$

(N-5) from TNB to Samanabad

Fig. 4. Comparison of $\mathrm{Pb}$ in soil samples along roadsides of a national highway and motorway at: a) $4 \mathrm{Km}$ from TNB, location 1 ; b) 8 $\mathrm{Km}$ from TNB, location 2; and c) $12 \mathrm{Km}$ from TNB, location 3; the $\mathrm{x}$-axis indicates distance in meters from the edge of the road while the $\mathrm{y}$-axis indicates the concentration of lead in ppm. 
spectroscopy. A high accumulation of lead was found in the roadside soil and vegetation of these linking roads. Lead contents were suggested to have originated mainly from vehicular emissions, which increase the lead concentration in roadside soil and plants. Lead contamination has found to be widely spread in soil and grass along these roads in Punjab, Pakistan. As lead can move along with wind in the wind direction, the concentration of lead was increased in the downwind direction. Moreover, all the concentrations of lead in soil and grass were found to be higher than their background values in Pakistan. It is concluded that lead pollution will become more severe in Pakistan in incoming future years [20].

\section{Lead Concentration in Close Proximity of Hudiara Drainage}

In Pakistan, industrial and sewage effluents are commonly used for raising crops. This common practice may result in the accumulation of metals to such an extent that they may become phytotoxic and eventually hazardous to human and animal health. One such example is the Hudiara drain, which is a transboundary channel and flows from India into Pakistan at Laloo village. Farmers of nearby locality continuously use the untreated wastewater to raise their vegetables and crops in more than 4000 acres of cultivated area. The drain water is lifted through tractor-driven devices, peter engines and electric pumps for the purpose of cultivation [21].

The soil of Hudiara drain contains a saturation level of $45-48 \%, \mathrm{pH} 7.9-8.1$ and organic matter content of $0.65-0.91 \%$; it is clay loam to loam in texture. Clay loam is the type of soil that is a combination of higher amounts of clay and rock material. Loam is a mixture in which more soil is present. In loam, soil particles have small size and this is very important property of loamy soil. Moisture lies in a range of $45-48 \%$ while $\mathrm{pH}$ (7.9-8.1) demonstrates its alkaline nature. Mostly soil is composed of $45 \%$ minerals; water is $25 \%, 25 \%$ air and 5\% organic matter. The organic matter of soil is small but very important as it gives nutrients and increases the water-holding capacity of soil and increases diversity.

Table 1 and Fig. 5 show the concentrations of lead $\left(\mathrm{mg} \mathrm{kg}^{-1}\right)$ in samples of soil irrigated with wastewater $\left(\mathrm{mg} \mathrm{kg}^{-1}\right)$ taken from a depth of 0-15 $\mathrm{cm}$. The graph in Fig. 5 shows considerably high levels of lead concentration in soil samples irrigated with wastewater. The reason is that nearly 600 industries are situated along Hudiara drain on both sides that are discharging

Table 1. Concentrations of lead in soil samples irrigated with wastewater $\left(\mathrm{mg} \mathrm{kg}^{-1}\right)$.

\begin{tabular}{|c|c|c|c|c|}
\hline \multirow{2}{*}{ Sample No. } & \multicolumn{2}{|c|}{ Soil at depth $0-15 \mathrm{~cm}$} & \multicolumn{2}{|c|}{ Soil at depth $15-30 \mathrm{~cm}$} \\
\hline & $\mathrm{Pb}$ concentration in $\mathrm{mg} / \mathrm{kg}$ & Standard deviation \pm SD & $\mathrm{Pb}$ concentration in $\mathrm{mg} / \mathrm{kg}$ & Standard deviation \pm SD \\
\hline 1 & 4.8 & \pm 0.02 & 2.12 & \pm 0.04 \\
\hline 2 & 5.00 & \pm 0.03 & 4.57 & \pm 0.03 \\
\hline 3 & 6.52 & $\pm 0,03$ & 5.8 & \pm 0.03 \\
\hline 4 & 7.52 & \pm 0.02 & 7.5 & \pm 0.02 \\
\hline 5 & 8.32 & \pm 0.03 & 9.4 & \pm 0.03 \\
\hline 6 & 9.91 & \pm 0.04 & 10.6 & \pm 0.02 \\
\hline 7 & 10.93 & \pm 0.03 & 10.9 & \pm 0.03 \\
\hline 8 & 11.3 & \pm 0.02 & 10.8 & \pm 0.04 \\
\hline 9 & 12.51 & \pm 0.01 & 11.42 & \pm 0.03 \\
\hline 10 & 22.4 & \pm 0.04 & 12.4 & \pm 0.02 \\
\hline 11 & 23.9 & \pm 0.02 & 12.7 & \pm 0.03 \\
\hline 12 & 24.6 & \pm 0.02 & 13.9 & \pm 0.02 \\
\hline 13 & 25.00 & \pm 0.03 & 15.0 & \pm 0.03 \\
\hline 14 & 25.8 & \pm 0.02 & 15.3 & \pm 0.04 \\
\hline 15 & 26.1 & \pm 0.03 & 19.8 & \pm 0.02 \\
\hline 16 & 26.66 & \pm 0.04 & 19.9 & \pm 0.03 \\
\hline 17 & 28.85 & \pm 0.02 & 20.8 & \pm 0.02 \\
\hline 18 & 29.1 & \pm 0.03 & 21.9 & \pm 0.01 \\
\hline 19 & 30.9 & \pm 0.02 & 22.9 & \pm 0.03 \\
\hline
\end{tabular}




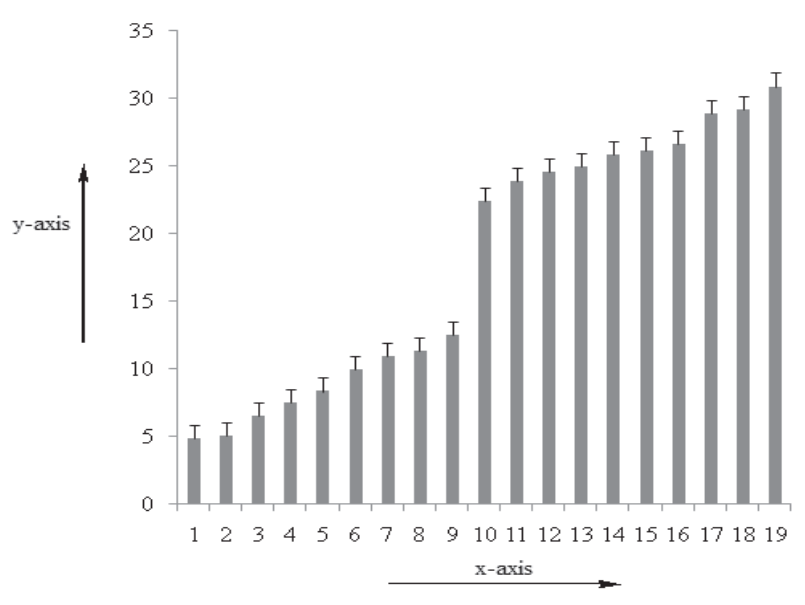

Fig. 5. Concentrations $\left(\mathrm{mg} \mathrm{kg}^{-1}\right)$ of lead in samples (soil depth $0-15 \mathrm{~cm}$ ) irrigated with wastewater; $\mathrm{x}$-axis indicates the number of the sample and $y$-axis demonstrates the concentrations of lead (ppm) in the sample.

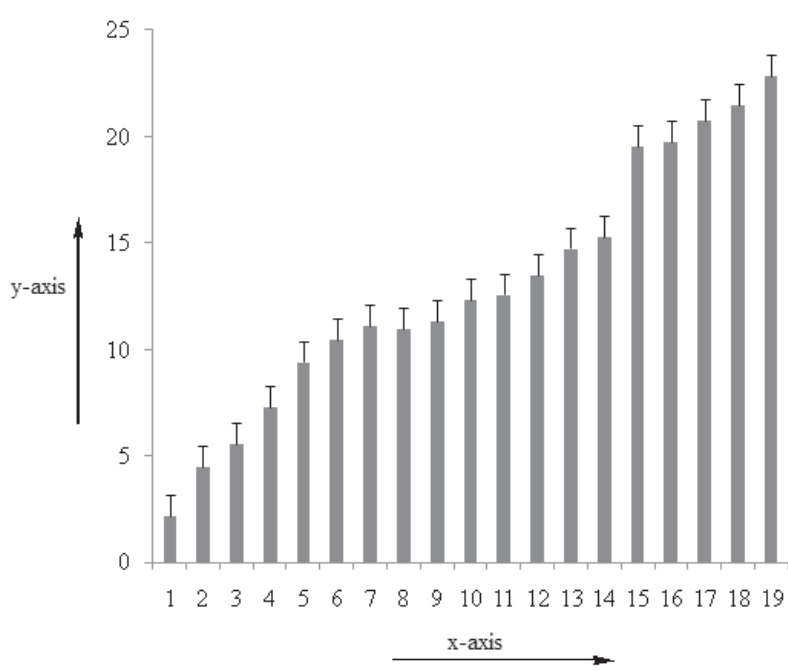

Fig. 6. Concentrations $\left(\mathrm{mg} \mathrm{kg}^{-1}\right)$ of lead in samples (soil depth $15-30 \mathrm{~cm}$ ) irrigated with wastewater; $\mathrm{x}$-axis indicates the number of the sample and y-axis demonstrates the concentration of lead (ppm) in the sample.

their effluents in Hudiara drain, which is the only drain in southern Lahore. Moreover, wastes of some areas of Lahore City and Cantonment, and some small villages are also dumped in this drain. The ultimate result is that the water of this drain is contaminated and unfit for the purpose of agriculture. Moreover, it also affects the aquatic life inside water and causes pollution in the soil layers in nearby irrigated areas.

Table 1 also shows concentrations of lead in soil samples irrigated with wastewater $\left(\mathrm{mg} \mathrm{kg}^{-1}\right)$ taken from a depth of $15-30 \mathrm{~cm}$. Nineteen samples in triplicate were taken, and analysis shows that lead concentration increases from 2.12 to $22.9 \mathrm{mg} / \mathrm{kg}$. But this concentration is less than the depth of $0-15 \mathrm{~cm}$ because lead does not readily dissolve in water, so the upper layer of soil contains more lead concentration as compared to the lower layer.

The results revealed that $\mathrm{Pb}$ content in the upper layer of soil ranges from 4.8 to $30.9 \mathrm{mg} / \mathrm{kg}$ and from 2.12 to $22.9 \mathrm{mg} / \mathrm{kg}$ in a slightly lower layer. The average of lead concentration in the upper layer is 19.42 and standard deviation is \pm 9.54 , and the average of lead concentration in the lower layer is 13.4 and standard deviation is \pm 6.18 . According to WHO (1996) and FAO (1985) limits, the metal concentration in the soil samples taken from different places was in the safe range. Soil $\mathrm{pH}$, the amount of organic matter, redox potential of soil and the rate of addition of metals mainly affect their adsorption, solubility and retention in soil. High heavy metal contents in dense traffic cities of Pakistan recorded concentrations of $10.06 \mathrm{mg} / \mathrm{kg}$, and the highest amount of lead was $29.7 \mathrm{mg} / \mathrm{kg}$. Similar results were shown along roadsides at various locations starting from $3.7 \mathrm{mg} / \mathrm{kg}$ to $272 \mathrm{mg} / \mathrm{kg}$ [22]. Comparable results were explained in Faisalabad city, Sheikhupura and Maredke and some areas of Rawalpindi. The deposition of lead in soil samples was less than the permissible limits [23].

Severe effects of the heavy metal concentration on the growth of plants have been reported [24] in Hudiara Drain. The phytoavailability of chromium in the presence of synthetic (commercially available urea) and natural (kitchen compost) fertilizers in Triticum aestivum was compared. It was concluded that germination of seeds was affected by higher concentrations of Hudiara water $(<70 \%)$; severe inhibitions were reported when seeds were grown in the soil with $80 \%$ of Hudiara drain water. Moreover, a significant higher concentration of metals was observed in plants (shoots and roots) grown in fertilized soil compared to the control. It was demonstrated that the wheat plants (Triticum aestivum) used for food purposes if irrigated with contaminated water can accumulate metals to toxic levels [24]. The presence of higher concentrations of metals in contaminated soil samples around the Hudiara drain as compared to other samples is due mainly to the growing population and anthropogenic sources. The increase of heavy metals as compared to the normally expected distribution in the soil makes it unsuitable for growing crops [25]. So there is a need to strictly monitor the water quality in the drain. There are external effects on groundwater quality in the vicinity of Hudiyara drain, so the release of industrial effluents into the drain should be avoided as the quality of this groundwater does not meet with the WHO and NSDWQ guidelines [26]. It is worth mentioning that the water supply in Lahore is totally dependent on groundwater, which creates a number of challenges due to an exploding population and mismanagement of groundwater resources. A number of pollutants are received by an unconfined aquifer from a poor drainage system, non-scientific landfills, and untreated industrial/dometstic effluents [27]. There are greater threats to the groundwater in Lahore region 
due to precipitation of air pollution, street runoff, industrial effluents, sewage and over-pumpage, etc. It was suggested that there is a need to strengthen the quality and monitoring network of groundwater levels in Lahore and also to adopt a modeling approach in order to study the factors that are responsible for the worst conditions of ground water in Lahore. Moreover, the surface drains in the city area should be regularly monitored and also the concept of earthen green belts/ dividers along the roads should be adopted [28]. The increase in heavy metal concentration due to special distribution in the groundwater of adjoining areas of Lahore (i.e., Sheikhupura) was reported. Since most of the area along the motorway to Muridkey road is occupied by a greater number of industries, 52, 45 and $20 \%$ of this area has concentrations of $\mathrm{Cd}$, $\mathrm{Co}$ and $\mathrm{Mn}$, respectively, which are higher than maximum permissible limits for irrigation purpose. However, the concentrations of $\mathrm{As}$ and $\mathrm{Cu}$ were found to be within safe limits except for a few patches [29]. The heavy metal concentrations were compared in soil, sewage water and in Raphanus sativus (L.), which was irrigated with municipal wastewater of Rawalpindi, Pakistan.

Considerable variations in heavy metals concentrations were found in the samples of soil, water and vegetables at three different growth stages [30]. The potential health risk of heavy metals (HMs) due to consumption of market food crops (MFCs) in Gujranwala and Sialkot districts, Pakistan, were evaluated. The concentrations of heavy metals such as lead and cadmium exceeded the Food and Agriculture/World Health Organization's recommended limits [31].

The vegetables and soil samples from different areas of Gujranwala (Pakistan) were investigated to evaluate some selected metals ( $\mathrm{Mn}, \mathrm{Pb}, \mathrm{Ni}, \mathrm{Cu}, \mathrm{Cd}$ and $\mathrm{Cr}$ ) with respect to industrialization. It was found that the concentrations of heavy metals in soil and vegetables depends on nutrient load in wastewater and industry type. The trend of bioaccumulation factor was $\mathrm{Cd}>$ $\mathrm{Cu}>\mathrm{Pb}>\mathrm{Ni}>\mathrm{Mn}>\mathrm{Cr}$ in cabbage, $\mathrm{Cu}>\mathrm{Cd}>\mathrm{Pb}>\mathrm{Ni}>\mathrm{Mn}>\mathrm{Cr}$ in spinach, $\mathrm{Cd}>\mathrm{Cu}>\mathrm{Pb}>\mathrm{Ni}>\mathrm{Mn}>\mathrm{Cr}$ in potato, $\mathrm{Cu}>\mathrm{Cd}>\mathrm{Ni}>\mathrm{Mn}>\mathrm{Cr}>\mathrm{Pb}$ in turnip, $\mathrm{Cd}>\mathrm{Cu}>\mathrm{Ni}>$ $\mathrm{Mn}>\mathrm{Cr}>\mathrm{Pb}$ in radish, $\mathrm{Cd}>\mathrm{Cu}>\mathrm{Ni}>\mathrm{Pb}>\mathrm{Mn}>\mathrm{Cr}$ in carrot and $\mathrm{Cu}>\mathrm{Cd}>\mathrm{Mn}>\mathrm{Ni}>\mathrm{Cr}>\mathrm{Pb}$ in round gourd. The increased levels of $\mathrm{Pb}, \mathrm{Ni}, \mathrm{Cr}, \mathrm{Cd}, \mathrm{Mn}$, and $\mathrm{Cu}$ in soil and vegetables were associated with urban pollution and industrial effluents [32]. The concentration of heavy metals was assessed in two commonly grown vegetables; brinjal (Solanum melongena) and okra (Abelmoschus esculentus) in three Multan (Pakistan) regions: Kot Abdul Fateh, Hamroot and Mozu Alamgir. All the tested samples of irrigation water, soil and vegetables were contaminated with heavy metals $(\mathrm{Pb}$, $\mathrm{Co}, \mathrm{Mn}, \mathrm{Cu}, \mathrm{Cd}$ and $\mathrm{Ni}$ ). The concentrations of lead were found to be exceptionally higher in both the vegetables as their irrigation source was wastewater [33].
Hudiara drain has been suggested as a case of Trans-boundary water pollution between Pakistan and India. It is one of the major reasons for both biological and chemical contamination in the Ravi River, with an annual discharge of about 180 cusecs waste water into the river. The stress on aquatic life and poor water quality in the Ravi is mainly attributed to this drain [34]. Heavy metal contamination of vegetables and fruits due to wastewater irrigation is under common investigation today. The concentration of heavy metals was investigated in vegetable and soil samples collected from agricultural areas around four major drains of Lahore (Kharak drain, Chota Ravi drain, Babu Sabu drain and Hudiara drain). It was concluded that the vegetables grown along these drains were contaminated with lead, chromium and copper in varying amounts. The concentrations of these metals was within the applicable permissible limits in the soil. However, vegetable concentrations were found to possess higher concentrations of lead and chromium. The use of wastewater as the irrigation source causes the potential accumulation of these metals in humans due to consumption of these vegetables [35]. The accumulation of heavy metals in guava (Psidium guajava) fruit was investigated from three Lahore sites Khurdpur, Mohlanwall and Lallo; these sites are irrigated by Hudiara drain water. Eleven heavy metals were detected using the proton-induced x-ray emission (PIXE) technique. The concentrations of $\mathrm{Zn}, \mathrm{Ni}, \mathrm{Fe}$, $\mathrm{Mn}, \mathrm{Cr}, \mathrm{Ti}, \mathrm{Ca}, \mathrm{K}, \mathrm{Al}, \mathrm{Mg}$ and $\mathrm{Na}$ in the study areas were significantly high when compared to permissible international standards. On the basis of recommended dietary and adequate intake allowance it was concluded that $P$. guajava supplies the highest amount of bio elements to the user organisms - especially of these areas. These results signal a threat to the entire ecosystem, including the human population, which can receive these pollutants directly [36].

Differenet vegetables irrigated by Manka Canal in the Dera Ghazi Khan District of Pakistan were analyzed for heavy metal contents. Spinach contained the highest concentrations of iron ( $968.25 \mathrm{mg} / \mathrm{kg})$, chromium $(6.62 \mathrm{mg} / \mathrm{kg})$ and managanese (137.3 $\mathrm{mg} / \mathrm{kg}$ ) exceeding the WHO safe limits of $425 \mathrm{mg} / \mathrm{kg}, 2.3 \mathrm{mg} / \mathrm{kg}$ and $2.2 \mathrm{mg} / \mathrm{kg}$, respectively. The melon possessed great potential to absorb nickel $(5.05 \mathrm{mg} / \mathrm{kg})$, which crossed the safe limit of $0.1 \mathrm{mg} / \mathrm{kg}$ while copper $(65 \mathrm{mg} / \mathrm{kg})$ was within the safe range. The zinc concentration $(41 \mathrm{mg} / \mathrm{kg})$ in brinjal did not cross the WHO reference limit of $73 \mathrm{mg} / \mathrm{kg}$. Cadmium was found in equal concentrations of $0.39 \mathrm{mg} / \mathrm{kg}$ (safe limit, $0.241 \mathrm{mg} / \mathrm{kg}$ ) in both brinjal and gourd. However, low levels of lead (as compared to those recommenended by $\mathrm{FAO} / \mathrm{WHO}$ ) were reported in all the vegetables. So it was concluded that there is a great need for regular monitoring of heavy metals in the vegetables grown in wastewater-irrigated areas [37]. Wastewater irrigation profoundly affects the heavy metal (HM) fractions, their contamination levels and bioavailability in the soil. 
The heavy metal concentrations were evaluated in soils irrigated with Hattar industrial wastewater. All HM fractions were significantly higher in the fields irrigated with industrial wastewater than rain-fed fields. After wastewater irrigation, the $\mathrm{HM}$ concentrations varied in the soils as $\mathrm{Pb}>\mathrm{Cu}>\mathrm{Ni}>\mathrm{Zn}>\mathrm{Fe}>\mathrm{Cd}>\mathrm{Mn}$. The $\mathrm{HM}$ concentration was found in the order of $\mathrm{Fe}>\mathrm{Zn}>\mathrm{Mn}>\mathrm{Pb}$ $>\mathrm{Cd}>\mathrm{Cu}>\mathrm{Ni}$ in rain-fed fields. Wastewater irrigation transforms HM into different fractions as residual > oxide associated $>$ carbonate associated $>$ organically bound $>$ exchangeable form. Repeated WW irrigation results in an increase of the soil $\mathrm{pH}$ and an increase of electrical conductivity [38]. So a regular monitoring of heavy metals in foodstuffs, water and soil was recommended in order to prevent their accumulation in the food chain [39]. Trace heavy metals such as $\mathrm{Cu}(\mathrm{II}), \mathrm{Pb}(\mathrm{II}), \mathrm{Zn}(\mathrm{II}), \mathrm{Cd}(\mathrm{II}), \mathrm{Ni}(\mathrm{II})$ and $\mathrm{Cr}(\mathrm{III})$ are rich in areas with high anthropogenic activities. Their concentrations were found to be several-fold higher (149\% for $\mathrm{Cr}, 131 \%$ for $\mathrm{Ni}, 176 \%$ for $\mathrm{Cd}, 139 \%$ for $\mathrm{Zn}$, $224 \%$ for $\mathrm{Pb}$ and $182 \%$ for $\mathrm{Cu}$ ) in downstream Swan River water samples of the Kahuta Industrial Triangle as compared to upstream. These metals were also present in higher concentrations in the milk samples collected from downstream as compared to the samples from upstream water-irrigated sites. The order of metal in milk was zinc $>$ chromium $>$ copper $>$ cadmium $>$ lead $=$ nickel. Such polluted water, soil and milk poses great health risks [40]. The soil from four land use areas (residential, commercial, industrial and agricultural) of Sheikhupura City, Pakistan was evaluated for $\mathrm{Cd}, \mathrm{Cr}, \mathrm{Cu}, \mathrm{Co}, \mathrm{Ni}, \mathrm{Zn}, \mathrm{Pb}, \mathrm{P}, \mathrm{K}, \mathrm{N}, \mathrm{CN}^{-}$, electrical conductivity and moisture content. High levels of $\mathrm{Cu}$, $\mathrm{Cd}, \mathrm{Pb}, \mathrm{CN}^{-}$were observed in agricultural soil. The lead $(\mathrm{Pb})$ concentration thrice exceeded permissible limits $(120 \mu \mathrm{g} / \mathrm{g})$. The increased concentration of pollutants in Sheikhupura City was attributed to industrialization, unlimited rural-to-urban migration pressures, and increasing population [41]. Heavy metal contamination is caused by various anthropogenic sources and poses a great threat to the environment. There were investigations on the soils, plants and waters of Madina town of Faisalabad, metropolitan area in 2010. The $\mathrm{Pb}$ and $\mathrm{Ni}$ concentrations were below the permissible limits, while concentrations of $\mathrm{Cd}$ in waters and plants were above the permissible limits [42]. In developing countries like Pakistan, the heavy metal toxicity is increasing day by day due to increasing trends of industrialization and urbanization [43]. Most industries in Pakistan discharge wastewater without any treatment, and such wastewater contains heavy concentrations of metals like cadmium and lead [44]. Investigations were done on agricultural soils and vegetables in various sites of Pakistan. The mean $\mathrm{Pb}$ concentration ranged $1.8-11 \mathrm{mgkg}^{-1}$ in edible parts of vegetables; it was higher in leafy vegetables as compared to the fruiting and pulpy vegetables [45]. Lead levels were studied in soil and five wild plant species (Ricinus communis, Cenchrus ciliaris, Parthenium hysterophorus, Datura alba and Calotropis procera) during all four seasons. A study of two busy roads - the Faisalabad-Sargodha road (FSR) and Pindi Bhattian to Lillah (M-2) in the Punjab, Pakistan - found higher levels of $\mathrm{Pb}$ in the plant and soil samples along both roads. FSR showed higher $\mathrm{Pb}$ contamination as compared to $\mathrm{M}-2$. The lead concentration was found to be higher during the summer season. Among all the plants studied, Calotropis procera showed the highest level of lead (3.98 $\mathrm{mg} \mathrm{kg}^{-1}$ dry wt.) among all four investigated plants [46].

It is crucial to establish the proper nutritional conditions to limit the metal uptake by plants from the soil of contaminated areas [47]. The heavy metal concentration can be decreased by avoiding irrigation with sewage water [33]. Various fungal species have been investigated as bioremediation agents for the removal of metals from a contaminated environment. The fungal population isolated from heavy metalcontaminated sites has the ability to resist higher concentrations of metals; Aspergillus niger was found to be the most resistant fungus in this regard. The resistance and tolerance of the isolates was majorly dependent upon the tested fungus rather than on the site of its isolation [48]. However, it has been found that the industrial effluent of the Hudiara drain has beneficial effects on the growth and element accumulation by Eucalyptus camaldulensis at early growth stage, as the mixing the Hudiara drain wastewater with tap water $(50: 50 \mathrm{v} / \mathrm{v})$ benefits the growth of E. camaldulensis [49]. There are also reports on the use of such contaminated soils as fertilizer or compost due to their high nutritional potential. Soil contamination and its nutritional potential were assessed for aesthetic beauty and near Samanabad Sewage Drain Lahore, Pakistan. Heavy metals, organic contents, phosphorus, potassium and soil electrical conductivity, were found to be relatively higher than standards. The high nutritional value of such soil enables it to be used as fertilizer or compost to enhance floral beauty through selective planting of salts and metal-tolerant ornamental plants. The data presented in this study provided a baseline for the planners to increase public awareness about soil contamination [50].

\section{Conclusions}

Qualitative and quantitative analyses of lead in soils along the motorway and national highway roadsides and Hudiara drain of Lahore have shown that lead $(\mathrm{Pb})$ concentration is relatively high in the soils of these areas. As roots have a tendency to absorb the toxic metals, plants should not be grown in leadinfected land. Crops planted by industrial effluents and wastewater accumulate and release these heavy metals. Although the amount of $\mathrm{Pb}$ in selected samples was in the allowable range of $\mathrm{WHO} / \mathrm{FAO}$, these can cause serious health issues in people who are consuming the 
crops of this contaminated area for a long period due to the magnification of lead. A comparison of the results with those of similar areas in Pakistan disclose that the soil in nearby areas of roads and waste drains contain a higher concentration of heavy metals, so proper monitoring and control procedures must be implemented in order to prevent the entry of these metals into the food chain. The use of some fungal strains may be effective for decreasing the concentration of pollutants in the wastewater.

\section{Conflict of Interest}

The authors declare no conflict of interest.

\section{References}

1. WASEEM A., ARSHAD J., IQBAL F., SAJJAD A., MEHMOOD Z., MURTAZA G. Pollution Status of Pakistan: A Retrospective Review on Heavy Metal Contamination of Water, Soil, and Vegetables. BioMed. Res. Int., 2014, 29, 2014.

2. HASSAN N.U., MAHMOOD Q., WASEEM A., IRSHAD M., PERVEZ A. Assessment of heavy metals in wheat plants irrigated with contaminated wastewater. Pol. J. Environ. Stud., 22, 115, 2013.

3. ULLAH Z., KHAN H., WASEEM A., MAHMOOD Q., FAROOQ U. Water quality assessment of the River Kabul at Peshawar, Pakistan: industrial and urban wastewater impacts. J. Water Chem. Techno., 35, 170, 2013.

4. DUBE A., ZBYTNIEWSKI R., KOWALKOWSKI T., CUKROWSKA E., BUSZEWSKI B. Adsorption and migration of heavy metals in soil. Pol. J. Environ. Stud., 10, 1, 2001.

5. PALIULIS D. Assessment of lake bottom sediment pollution by lead and cadmium. Pol. J. Environ. Stud., 23, 1273, 2014.

6. ADELEKAN B.A., ABEGUNDE K.D. Heavy metals contamination of soil and groundwater at automobile mechanic villages in Ibadan, Nigeria. Int. J. Phy. Sci., 6, 1045, 2011.

7. KABATA-PENDIAS A., PENDIAS H. Biogeochemistry of trace elements. PWN, Warszawa. Polish Google Scholar. 1999.

8. SĄKOL G., MIROSŁAWSKI J., BREWCZYŃSKI P.Z. Efficient $\mathrm{pb}$ translocation by 'purple petticoats' cv. of heuchera 1 . from contaminated soil in a coal basin. Pol. J. Environ. Stud., 23, 2199, 2014.

9. HAAR G.L.T., BAYARD M.A. Composition of airborne lead particles. Nature., 232, 553, 1971.

10. ANIELAK A.M., SCHMIDT R. Sorption of lead and cadmium cations on natural and manganese-modified zeolite. Pol. J. Environ. Stud., 20, 43, 2011.

11. KAZI T.G., SHAH F., SHAIKH H.R., AFRIDI H.I., SHAH A., ARAIN S.S. Exposure of lead to mothers and their new born infants, residents of industrial and domestic areas of Pakistan. Environ. Sci. Pollut. Res., 21, 3021, 2014.

12. MISRA S., MANI D. Soil pollution. New Delhi, India, S. B Nangia APH Publishing Corporation. 29, 2009.

13. WASEEM A., ARSHAD J., IQBAL F., SAJJAD A., MEHMOOD Z., MURTAZA G. Pollution status of Pakistan: a retrospective review on heavy metal contamination of water, soil, and vegetables. BioMed. Res. Int., ID 813206, 29, 2014.

14. KHAN S., CAO Q., ZHENG Y.M., HUANG Y.Z., ZHU Y.G. Health risks of heavy metals in contaminated soils and food crops irrigated with wastewater in Beijing, China. Environ. Pollut., 152, 686, 2008.

15. BROWN R.W., GONZALES C., HOOPER M.J., BAYAT A.C., FORNERETTE A.M., MCBRIDE T.J., MIELKE H.W. Soil lead $(\mathrm{Pb})$ in residential transects through Lubbock, Texas: a preliminary assessment. Environ. Geochem. Hlth., 30, 541, 2008.

16. WIECZOREK J., WIECZOREK Z., BIENIASZEWSKI T. Cadmium and lead content in cereal grains and soil from cropland adjacent to roadways. Pol. J. Environ. Stud., 14, 535, 2005.

17. MOCEK-PŁOCINIAK A. Effect of mineral xenobiotics on the enzymatic activity of anthropogenically changed soils. Polish J. of Environ. Stud., 18, 421, 2009.

18. FAROOQ Y.J.H., AHMAD M.R., AFZAL M., KHAN S.A. Lead pollution measurement along national highway and motorway in Punjab, Pakistan. Journal of Basic Applied Sciences., 8, 463, 2012.

19. JANKIEWICZ B., ADAMCZYK D. Assessing Heavy Metal Content in Soils Surrounding the Łódź EC4 Power Plant, Poland. Polish J. of Environ. Stud., 16, 933, 2007.

20. KABATA-PENDIAS A., PENDIAS H. Biogeochemistry of trace elements, PWN, Warszawa, 1999.

21. YAMIN M.T., AHMAD N. Influence of Hudiara drain water irrigation on trace elements load in soil and uptake by vegetables. JASEM., 11, 169, 2007.

22. ATIEMO M.S., OFOSU G.F., KURANCHIE-MENSAH H., TUTU A.O., PALM N.D., BLANKSON S.A. Contamination assessment of heavy metals in road dust from selected roads in Accra, Ghana. Research Journal of Environmental and Earth Sciences, 3, 473, 2011.

23. KHAN M.A., GHOURI A.M. Environmental pollution: Its effects on life and its remedies. RW-JASC, 2, 276, 2011.

24. NISAR N., AAMIR K.. Phytoavailability of chromium in Triticum Aestivum in natural and synthetically fertilized soil irrigated with hudiara drain wastewater, Lahore. IJAAR., 4, 34, 2014.

25. IRAM S., AHMAD I., STUBEN D. Analysis of mines and contaminated agricultural soil samples for fungal diversity and tolerance to heavy metals. Pak. J. Bot., 41, 885, 2009.

26. HAYDAR S., HAIDER H., NADEEM O., HUSSAIN G., JALEES I., QADEER A. Effect of Hudiara drain on the quality of groundwater in the housing schemes of Lahore. Journal of Faculty of Engineering Technology., 21, 119, 2014.

27. AKHTAR M.M., TANG Z., MOHAMADI B. Contamination potential assessment of potable groundwater in Lahore, Pakistan. Pol. J. Environ. Stud., 23, 1905, 2014.

28. HASSAN G.Z., HASSAN F.R., AKHTAR S. Environmental Issues and Concerns of Groundwater in Lahore. Proc. Pak. Acad. Sci., 53, 163, 2016.

29. QAZI M.A., KHATTAK M.A., KHAN M.S.A., CHAUDHRY M.N., MAHMOOD K., AKHTER B., IQBAL N., ILYAS S., ALI U.A. Spatial distribution of heavy metals in ground water of Sheikhupura District Punjab, Pakistan. J. Agric. Res., 52, 99, 2014.

30. GUL R. The analyses of heavy metal concentrations in soil, waste water and Raphanus sativus (L.) at three different growth stages, 2016.

31. KHAN M.U., MALIK R.N., MUHAMMAD S., ULLAH F., QADIR A. Health risk assessment of consumption 
of heavy metals in market food crops from Sialkot and Gujranwala Districts, Pakistan. Hum. Ecol. Risk Assess., 21, 327, 2015.

32. QADIR A., AMINA., KANWAL Q., BANO R., YOUSAF B. Accessing potential bioaccumulation of heavy metals in selective vegetables from Gujranwala District. Pakistan Journal of Environment and Earth Science. 5, 58, 2015.

33. RANDHAWA M., AHMAD G., ANJUM F., ASGHAR A., SAJID M. Heavy metal contents and their daily intake in vegetables under peri-urban farming system of Multan, Pakistan. Pak. J. Agr. Sci., 51, 1025, 2014.

34. KHAN M., KHAN N., ASLAM H. Hudiara drain-a case of trans-boundary water pollution between India and Pakistan. Pak. J. Biol. Sci., 6, 167, 2003.

35. KHAN M., KHAN N., ASLAM H. Hudiara drain-a case of trans-boundary water pollution between India and Pakistan. Pak. J. Biol. Sci., 6, 167, 2003.

36. MUHAMMAD H., AYUB M., IQBAL Z., ANWAR MALIK M. Heavy Metals Toxicity in Psidium guajava Irrigated by Polluted Water of Hudiara Drain in District Lahore, Punjab, Pakistan. Biologia (Pakistan), 59, 239, 2013.

37. LATIF A., BILAL M., ASGHAR W., AZEEM M., AHMAD M. I., ABBAS A., AHMAD M.Z., SHAHZAD T. Heavy metal accumulation in vegetables and assessment of their potential health Risk. J. Environ. Anal. Chem., 5, 234, 2018.

38. HAROON B., PING A., PERVEZ A., FARIDULLAH IRSHAD M. Characterization of heavy metal in soils as affected by long-term irrigation with industrial wastewater. J. Water Reuse Desal., 9, 47, 2018.

39. KACHOLI1 D.S., SAHU M. Levels and health risk assessment of heavy metals in soil, water, and vegetables of Dar es Salaam, Tanzania. J. Chem., Article ID 1402674, 9, 2018.

40. PERVEEN I., RAZA M.A., SEHAR S., NAZ I., YOUNG B., AHMED S. Heavy metal contamination in water, soil, and milk of the industria area adjacent to Swan River, Islamabad, Pakistan. Hum. Ecol. Risk Assess., 23, 2017. doi.org/10.1080/10807039.2017.1321956.

41. AKHTAR S., AYAZ K., INAYAT S., AHMAD S.R. Distribution of selected heavy metals in urban, suburban and agricultural soils in Pakistan. Bull. Env. Pharmacol. Life Sci., 7, 77, 2018.
42. FARID G., SARWAR N., SAIFULLAH AHMAD A., GHAFOOR A. Heavy metals (Cd, $\mathrm{Ni}$ and $\mathrm{Pb}$ ) contamination of soils, plants and waters in Madina Town of Faisalabad Metropolitan and preparation of Gis Based Maps. Adv. Crop Sci. Tech., 4, 199, 2015. doi:10.4172/23298863.1000199.

43. SAJID M., YOUNUS M., KHAN M.U.R., ANJUM A.A., HAQUE S.E.U., RAFIQUE M.K., ZAMAN M.A., KHAN A.U. Effects of lead on hematological and biochemical parameters in Lohi sheep grazing around a sewerage drain. Pak. Vet. J., 37, 450, 2017.

44. HINA K., ARSHAD M., LATIF H., GHAFOOR A., RAFIQUE H. Sorption of metals by tree bark from synthetic contaminated water. Pak. J. Agri. Sci., 54, 271, 2017.

45. REHMAN Z., KHAN S., BRUSSEAU M.L., SHAH M.T. Lead and cadmium contamination and exposure risk assessment via consumption of vegetables grown in agricultural soils of five-selected regions of Pakistan. Chemosphere., 168, 1589, 2017.

46. KHALID N., HUSSAIN M., YOUNG H.S., ASHRAF M., HAMEED M., AHMAD R. Lead concentrations in soils and some wild plant species along two busy roads in Pakistan. Bull. Environ. Contam. Toxicol. 100, 250, 2018.

47. MAGLOVSKI M., GERSI Z., RYBANSKY L., BARDACOVA L., MORAVCIKOVA J., BUJDOS M., DOBRIKOVA A., APOSTOLOVA E., KRAIC J., BLEHOVA A., MATUSÍKOVA I. Effect of nutrition on wheat photosynthetic responses to arsenic stress. Pol. J. Environ. Stud., 28, 1821, 2019.

48. IRAM S., ZAMAN A., IQBAL Z., SHABBIR R. Heavy Metal Tolerance of Fungus Isolated from Soil Contaminated with Sewage and Industrial Wastewater. Pol. J. Environ. Stud., 22, 691, 2013.

49. SHAH F.U.R., AHMAD N., MASOOD K.R., PERALTA-VIDEA J.R., ZAHID D.M., ZUBAIR M. Response of Eucalyptus camaldulensis to irrigation with the Hudiara drain effluent. Int. J. Phytoremediat., 12, 343, 2010.

50. RAZA H.H.H., KHAWER S., FAROOQ U., ATHAR M., ATIF S. Assessment of Soil Contamination near Samanabad Sewage Drain and its Nutritional Potential for Aesthetic Beauty. J Earth Sci Clim Change., 5, 2, 2013. 